American Journal of Immunology 5(2): 56-60, 2009

ISSN 1553-619X

(C) 2009 Science Publications

\title{
A Model of Intestinal Anaphylaxis in Whey Sensitized Balb/c Mice
}

\author{
Negaoui Hanane, Kaddouri Hanane, Kheroua Omar and Saidi Djamel \\ Laboratory of Physiology of Nutrition and Food Safety, Department of Biology, \\ Faculty of Science, University of Oran, Algeria
}

\begin{abstract}
Problem statement: Cow's Milk Allergy (CMA) is a common disease in childhood. Pathophysiological mechanisms involved in gastrointestinal symptoms are relatively poorly understood. Approach: Therefore, an experimental model of intestinal anaphylaxis was needed to approach the problem. The aim of this study was to examine the effect of the parenteral sensitization to whey proteins through immune response and local intestine inflammation using a murine model of allergy. Sensitization of Balb/c mice with $\beta$-lactoglobulin $(\beta-\mathrm{Lg})$ or whey was performed in presence of Alum $\mathrm{Al}(\mathrm{OH} 3)$. Mice were analyzed for $\beta$ - $\mathrm{Lg}$ or whey specific serum antibodies by ELISA. Local anaphylactic responses were performed in vitro in using chamber by intestine challenge with $\beta$-Lg or whey. Histological study was used to assess gut inflammation. Results: The sensitization induced the production of anti- $\beta$ - $\mathrm{Lg}$ or anti whey $\operatorname{IgG}, \operatorname{IgG} 1, \operatorname{IgG} 2 \mathrm{a}$ and $\operatorname{IgE}$ with a high $\operatorname{IgG} 1 / \operatorname{IgG} 2$ a ratio translating Th2 type response. The addition of $\beta-\mathrm{Lg}$ or whey to the serosal side of the mouse intestinal epithelium in using chamber produced electrogenic chloride secretion as shown by Isc stimulation. Histological findings were mild with villi atrophy and lymphocyte hyperplasia. Conclusion: After sensitization, the mice became prone to developing anaphylactic response and may be useful experimental model for mechanistic studies of CMA or for hydrolyzed formulae.
\end{abstract}

Key words: Cow's milk allergy, whey, murine model, $\operatorname{IgE}$, IgG1, anaphylactic response

\section{INTRODUCTION}

Cow's milk is one of the most common causes of food allergy in the first years of life. Approximately $2.4 \%$ of infants exhibit cow's milk hypersensitivity ${ }^{[1]}$. Cow's Milk Allergy (CMA) is an adverse immunological response to cow's Milk Proteins (CMP) affecting the cutaneous, intestinal or respiratory systems. Clinical symptoms involve immediate or delayed reactions. Immediate reactions are mainly $\operatorname{IgE}$ dependant. A cell mediated reaction type IV has been suggested in the development of local lesion in the small intestinal mucosa referred to protein entheropathy ${ }^{[2,3]}$. Vomiting and diarrhoea are common features of milk hypersensitivity. Pathophysiological mechanisms involved in gastrointestinal symptoms are relatively poorly understood because of the difficulty accessing the gastrointestinal tract ${ }^{[4,5]}$ Studies in humans are often limited for obvious ethical reasons, but the use of animal models offers the ability to study sensitization. Animal models of intestinal hypersensitivity were mostly obtained by sensitizing parenterally rat ${ }^{[6]}$, rabbit $^{[7]}$ or guinea pig ${ }^{[8]}$ to cow's milk proteins. Murine models have been useful tools for the study of allergy diseases which involved share mechanisms in human and murine immune system such as Th1 and Th2 responses ${ }^{[9]}$. No study examined allergic reaction due to bovine milk using mice as a model of intestinal anaphylaxis. As a result, the present study was designed to investigate the effect of specific sensitization to cow's milk proteins on the systemic and intestinal response of Balb/c mice used as a model of allergy.

\section{MATERIALS AND METHODS}

Bovine whey: Cow's milk freshly collected from a local farm was skimmed. Whey was obtained by caseinates precipitation at $\mathrm{pH} 4.6$ by $0.1 \mathrm{~N} \mathrm{HCl}$ additions. The protein content in whey was measured by the Lowry method. To analyze protein composition of whey SDS-PAGE was carried out on whey.

Immunization protocol: Female Balb/c mice (5-7 weeks old) were purchased from Pasteur Institute d'Alger. Mice were fed and watered ad libitum for 1 week before use. Two groups of mice $(n=20$ /groups) were immunized on days 0,14 and 28 by intraperitoneal

Corresponding Author: Saidi Djamel, Laboratory of Physiology of Nutrition and Food Safety, Department of Biology, Faculty of Science, University of Oran, Algeria Tel: 213550231610 Fax: 21341581925 
injection of $10 \mu \mathrm{g} \beta$-lactoglobulin or $20 \mu \mathrm{g}$ whey adsorbed on to $2 \mathrm{mg}$ of alum $\mathrm{Al}\left(\mathrm{OH}_{3}\right)$ in $0.1 \mathrm{~mL}$ of PBS. Additional groups $(n=6)$ of naïve mice were used as control. Blood was obtained on days 35 by. Sera were collected and stored at $-20^{\circ} \mathrm{C}$ until analysis.

Antibody levels: Specific anti $\beta$-lactoglobulin and anti whey antibodies were assayed in serum samples using an Enzyme-Linkind Immunosorbent Assay (ELISA). Microtiter plates (Maxisorp; Nunc, Denmark) were coated with $\beta$-lactoglobulin or whey $\left(100 \mu \mathrm{g} \mathrm{mL}^{-1}\right)$ in phosphate buffered saline (PBS) $\mathrm{pH} 7.4$ for $48 \mathrm{~h}$. After overnight incubation at $4{ }^{\circ} \mathrm{C}$, plates were washed and blocked with $3 \%$ BSA PBS (for the plates containing $\beta$ $\mathrm{Lg}$ ) or $2 \%$ fish gelatine (for the plates containing whey). After incubation for $1 \mathrm{~h}$ at $37^{\circ} \mathrm{C}$ and washing the plates, $50 \mu \mathrm{L}$ of serum samples were added to the plates and incubated for $2 \mathrm{~h}$ at $37^{\circ} \mathrm{C}$. Plates were then washed and incubated for $1 \mathrm{~h}$ at $37^{\circ} \mathrm{C}$ with $50 \mu \mathrm{L}$ of $2 \mu \mathrm{g} \mathrm{mL}$ biotinylated polyclonal specific antibody for IgG (Sigma, B9904, France), of biotinylated monoclonal specific antibodies (Pharmingen, France) for IgE (553387/R1915), IgG1 (553440/A85-1) IgG2a (553387/R19-15). Fifty (50) $\mu \mathrm{L}$ of streptavidin-peroxydase (1:5000 dilution, $\mathrm{E}$ 2886, Sigma; France) were then added to the plate and incubated for $30 \mathrm{~min}$ at $37^{\circ} \mathrm{C}$. The reaction was revealed by addition of $50 \mu \mathrm{L}$ of $\mathrm{H}_{2} \mathrm{O}_{2}\left(30 \%, 0.25 \mathrm{~mL} \mathrm{~L}^{-1}\right.$; Sigma, France) associated with diamino-orthophenylene (OPD) (0.5 mg mL $\mathrm{m}^{-1}$; Sigma, France) in sodium citrate buffer $0.05 \mathrm{M}$ pH5.1. The reaction was stopped by adding $\mathrm{H}_{2} \mathrm{SO}_{4}(2 \mathrm{~N})$. The plates were read at $492 \mathrm{~nm}$ on an automated Elisa reader (ELx800, Bio-Tek Instruments GmbH, Germany).

Tissue preparation: Thirty five days after the first immunization, mice were killed by intraperitoneal administration of sodium penthothal $\left(50 \mathrm{mg} \mathrm{kg}^{-1}\right)$. A segment of jejunum $10-20 \mathrm{~cm}$ in length was removed and placed in ice-cold oxygenated Ringer solution containing (ionic composition in $\mathrm{mM}$ : $\mathrm{Na}^{+} 140 \mathrm{mM}, \mathrm{K}^{+}$ 5.2, $\mathrm{Ca}^{++} 1.2, \mathrm{Mg}^{++} 1.2 \mathrm{mM}, \mathrm{Cl}^{-} 120 \mathrm{mM}, \mathrm{HCO}_{3}^{-}$ $25 \mathrm{mM}, \mathrm{HPO}_{4} 2.4 \mathrm{mM}, \mathrm{H}_{2} \mathrm{PO}_{4} 0.4 \mathrm{mM}$.

Measurement of mucosal ion transport: Jejunal segments were opened longitudinally along the anti mesenteric border and placed in ice cold oxygenated solution.

The jejunum was mounted at flat sheets between two Lucite halves using chamber having a flux area of $0.1 \mathrm{~cm}^{2}$. Both sides of each mucosal sheet were bathed in the Ringer solution which was maintained at $\mathrm{pH} 7.4$ and $37^{\circ} \mathrm{C}$ oxygenated continuously with $5 \% \mathrm{CO}_{2}$ and $95 \% \mathrm{O}_{2}$. The solutions bathing the serosal and mucosal sides of the tissue were connected to calomel electrodes via agar bridges $(3 \mathrm{M} \mathrm{KCl})$ for measurement of transepithelial Potential Difference (PD) and to Ag$\mathrm{AgCl}$ electrodes for the passage of current through the system. The PD was recorded continuously and at regular intervals, the $\mathrm{PD}$ was turned off by passing a $10 \mu \mathrm{A}$ current. Current pulses allowed measurement of the tissue Isc and conductance $(\mathrm{G})$ at regular intervals. After electrical parameters stabilization (20-30 min), the respective effects of $\beta$-Lg and whey were measured by adding these milk proteins at the serosal side of the tissue. In some experiments, tissues were pretreated with furosemide $(10 \mu \mathrm{M})$. This substance was added to the serosal bathing medium $5 \mathrm{~min}$ before serosal challenge with $\beta$ - $\mathrm{Lg}$ or whey. At the end of the experiment, glucose was added at a concentration of $10 \mathrm{mM}$ to both luminal and serosal bathing medium.

Histological analysis: Changes in the intestinal mucosa were evaluated at 35 days of the experiments. A jejunal segment was taken for histological analysis. The jejunum was fixed in $10 \mathrm{mM}$ formalin in PBS, embedded in paraffin and cut into 3-5 $\mu \mathrm{m}$ thick section. The sections were stained with hematoxylin-eosin for general analysis.

Measurement of the length of villi at the jejunum were performed using an optical microscope equipped with a micrometer.

Statistical analysis: Statistical analysis for significant differences between two groups was performed using student's t-test and statistical differences are reported at $\mathrm{p}<0.05$.

\section{RESULTS}

We first analyzed the proteins in whey. As shown in Fig. 1, electrophoretic profile of whey showed the presence of protein bands identified by the kit marker. It corresponded to Bovine serum albumin (BSA), $\beta$ lactoglobulin $(\beta$-Lg) and $\alpha$-lactalbumin $(\alpha-\mathrm{La})$.

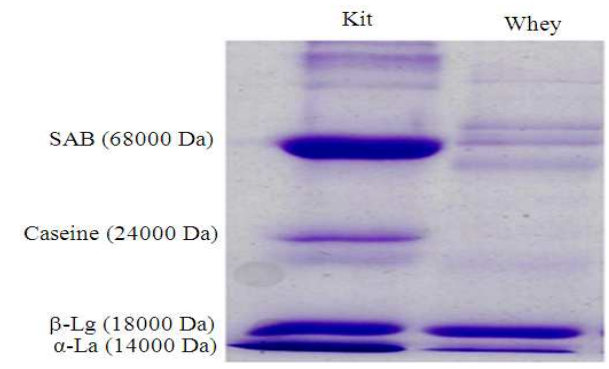

Fig. 1: SDS-PAGE analysis of whey proteins. The protein bands visualized by Coomassie brilliant blue were analyzed in comparison to a molecular weight marker 


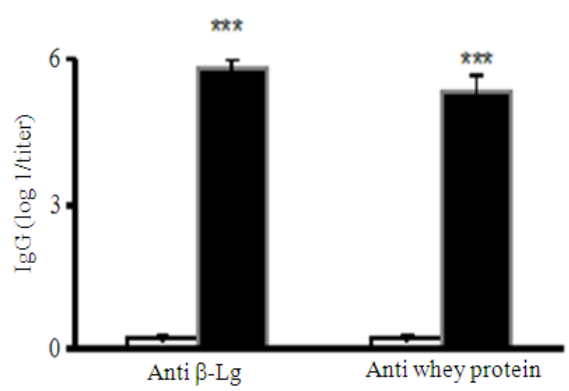

(a)

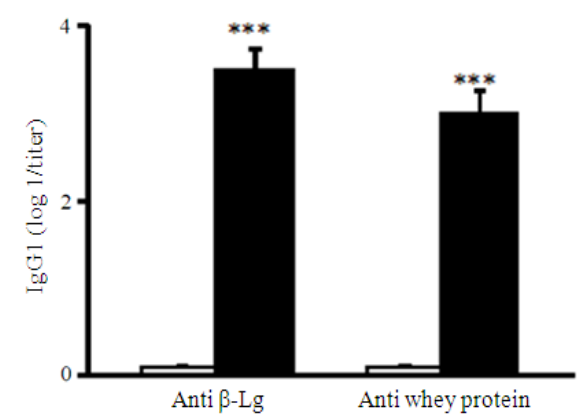

(c)

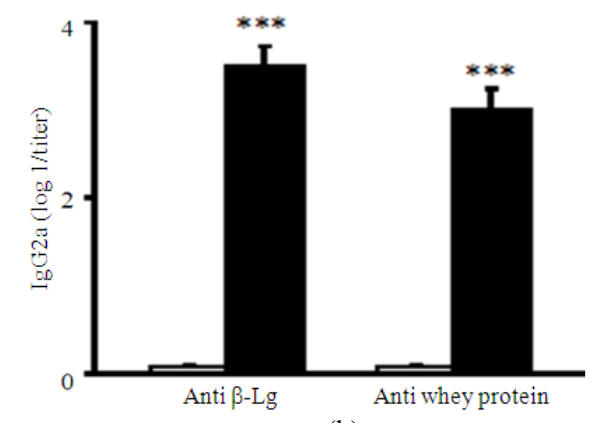

(b)

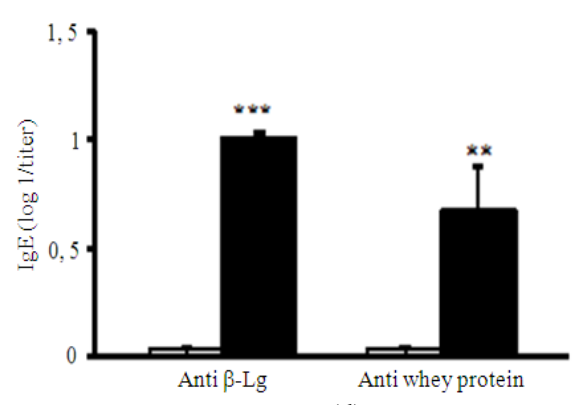

(d)

Fig. 2: Antibody responses to $\beta$ - $\mathrm{Lg}$ and whey in control (open columns) and immunized (dark columns) mice. *: $\mathrm{p}<0.05 ; * *: \mathrm{p}<0.01 ; * * *: \mathrm{p}<0.001$

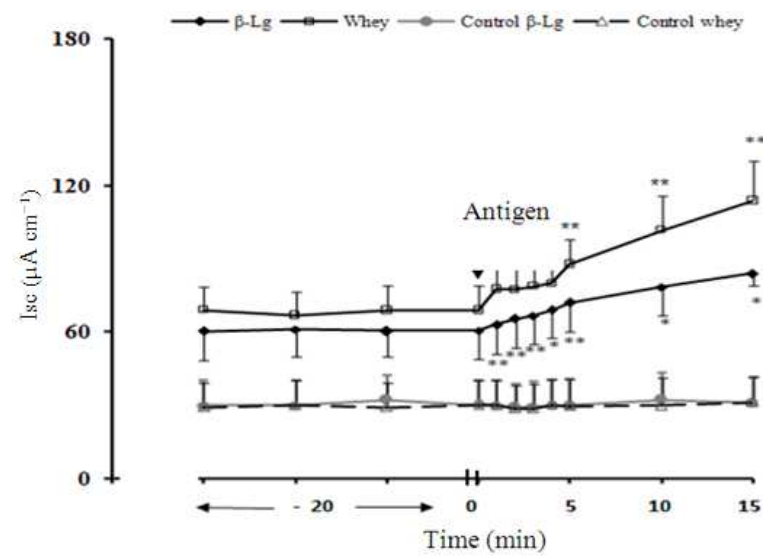

Fig. 3: Change in short current circuit (Isc) in response to $\beta$-Lg or whey protein challenge in control and sensitized mice. The data (mean $\pm \mathrm{SE}, \mathrm{n}=6$, *: $\mathrm{p}<0.04, * *: \mathrm{p}<0.01, \mathrm{p}$-value represents the comparison of $\beta$-Lg or whey protein response on Isc before (t0) and after challenge

Antibody response: Antibody responses were characterized in Balb/c mice sensitized to $\beta$ - Lg or whey in the presence of alum. This protocol of sensitization promoted IgG, IgG2a and IgE response (Fig. 2) with positive $\operatorname{IgG} 1 / \mathrm{IgG} 2 \mathrm{a}$ ratio translating a Th2 type response.

Hypersensitivity response to $\beta-\mathrm{Lg}$ and whey: Hypersensitivity response of mice was further evaluated in using chamber by measurement of the response to antigen challenge on the serosal side of jejunum. Challenge of an isolated jejunal segment with $\beta-\mathrm{Lg}$ or whey induced an important increase in Isc in sensitized mice but not in control animals. The Isc increased within 1 min after challenge with $\beta-\mathrm{Lg}$ whereas after challenge with whey Isc changes occurred within $5 \mathrm{~min}$ (Fig. 3). To delineate the nature of observed ion secretion, we applied a $\mathrm{Na}^{+} / \mathrm{K}^{+} / 2 \mathrm{Cl}^{-}$cotransport blocker to the serosal surface of tissue prior to the challenge with $\beta$-Lg or whey. Although furosemide alone had no effect on baseline Isc in sensitized tissues, this blocker significantly abolished changes in Isc induced by serosal challenge to antigens (Fig. 4). These results indicated that transepithelial $\mathrm{Cl}^{-}$secretion was the ion involved in the secretory response in the mice small intestine to antigen challenge. Initial baseline conductance was also not different between groups (Table 1). However, conductance was significantly increased in $\beta-\mathrm{Lg}$ and in sensitized whey. In contrast, control mice maintained a stable conductance throughout the experimental period. 
Table 1: Conductance (G) of mice jejunum tissues before and after $\beta$ $\mathrm{lg}$ and whey addition in control and immunized mice $\mathrm{G}\left(\mathrm{mmho} \mathrm{cm}^{-2}\right)$

\begin{tabular}{llll} 
& \multicolumn{2}{l}{ Before challenge } & After challenge \\
\hline Control & $28.60 \pm 2.92$ & $\beta-\mathrm{Lg}$ & $32.95 \pm 3.91$ \\
Immunized with $\beta-\mathrm{Lg}$ & $34.59 \pm 5.31$ & & $45.26 \pm 6.02^{* *}$ \\
Control & $24.94 \pm 4.07$ & whey & $31.15 \pm 4.58$ \\
Immunized with whey & $17.94 \pm 7.32$ & & $37.17 \pm 15.17^{*}$ \\
\hline
\end{tabular}

The data (mean \pm SE, $n=6$, *: $p<0.05 * *: p<0.01$, p-value represents the comparison of $\beta-\mathrm{Lg}$ or whey protein response on $\mathrm{G}$ before and after challenge

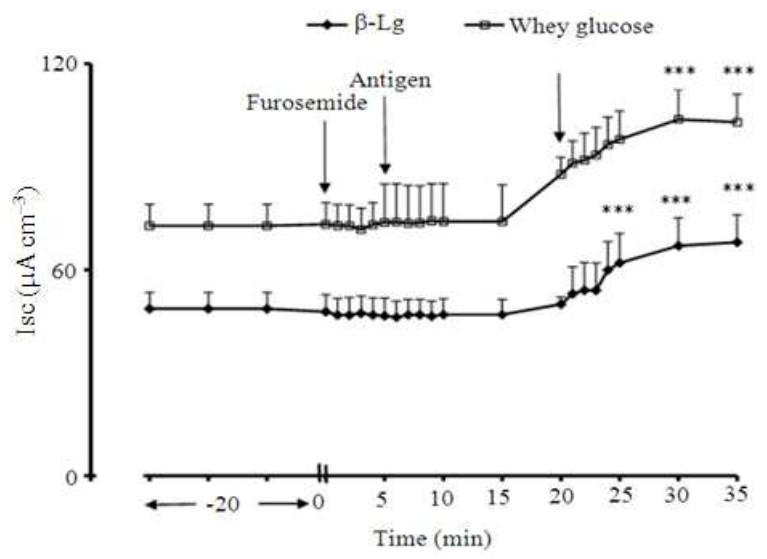

Fig. 4: Effect of furosemide on Isc response to $\beta$ - $\mathrm{Lg}$ or whey challenge in immunized mice. At the end of the experiment, glucose is added at the concentration $10 \mathrm{mM}$ in serosal and luminal sides. Data (mean $\pm \mathrm{SE}, \mathrm{n}=6$, ***: $\mathrm{p}<0.001$, $\mathrm{p}$ value represents the comparison effect on Isc before and after glucose addition

Histological study: Morphological changes of jejunum induced by sensitization of mice to milk proteins were examined by optical microscopy. In the control group, the villi appeared long and fine, bordered by a simple unistratified epithelium, mainly composed of tall cells with a flat striatus containing regular nuclei at the base and corresponding to the enterocytes. Moreover, the lamina propria appeared to be fibrous and polymorphous presented small abundance corresponding to immune system cells (intraepithelial lymphocytes LIE). In contrast, the intestinal mucosa of immunized mice presented major atrophy with pseudo-stratified epithelium (Fig. 5). The length of villi in sensitized mice with $\beta-\mathrm{Lg}$ $(38.61 \pm 0.76 \mu \mathrm{m}, \mathrm{p}<0.0005)$ or whey $(39.46 \pm 0.89 \mu \mathrm{m}$, $\mathrm{p}<0.0005)$ were significantly reduced compared to control $(49 \pm 1.15 \mu \mathrm{m})$. The number of LIE was so high that it wasn't possible to count.
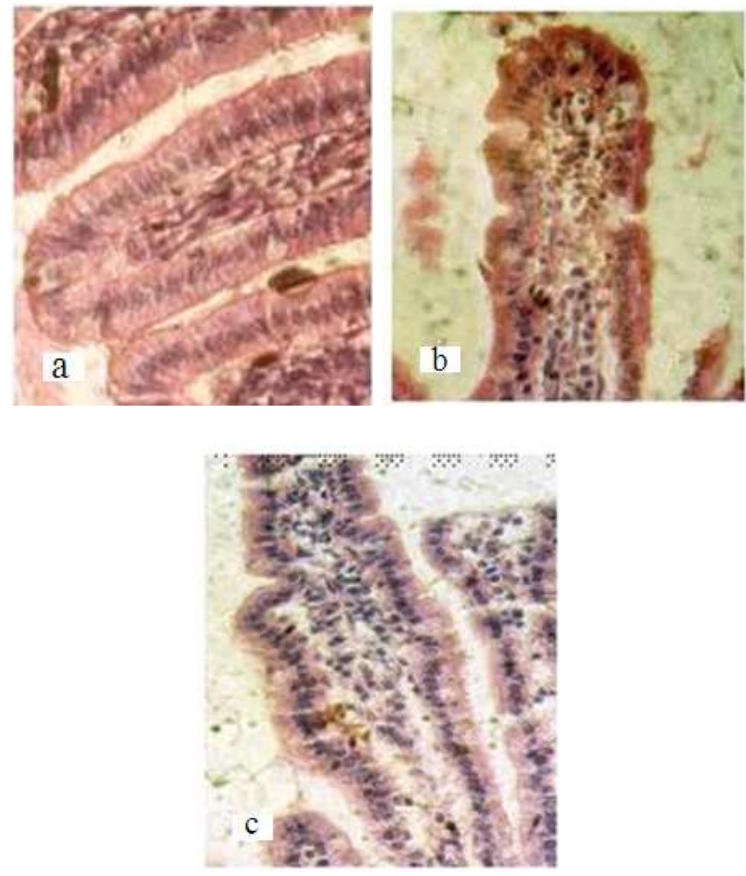

Fig. 5: Optical microscopy $(\mathrm{G} \times 25)$ of jejunal villi from control (a): Immunized mice with whey (b): $\beta$-Lg (c): Stained with hemalun-eosine

\section{DISCUSSION}

In this study we investigated the impact of parenteral sensitization on systemic and intestinal response using the bovine whey and its major protein $(\beta-\mathrm{Lg})$. We showed that the antigens introduction via the parenteral route in the presence of Alum $\mathrm{Al}\left(\mathrm{OH}_{3}\right)$ induced high levels of antibodies production. In this case, IgG1 and IgE levels were profoundly induced and the $\operatorname{IgG} 1 / \operatorname{IgG} 2$ a ratio was high suggesting a Th2 type response. The activation of $\mathrm{Th} 2$ cells characterizes allergy disease ${ }^{[10]}$. However, IgG1 and IgE production should be considered insufficient to predict allergic response. Hence, consideration should be given to the assessment of the hypersensitivity reaction by challenging with sensitizing antigen using in vivo/ in vitro methods. In the present study, allergic response was studied in murine intestine after challenging with $\beta$-Lg or whey. Results showed that in vitro stimulation of jejunum from sensitized mice to $\beta-\mathrm{Lg}$ or whey induced a significant increase in Isc. The response was antigen specific and was inhibited by furosemide. By inhibiting $\mathrm{Na}^{+} / \mathrm{K}^{+} / 2 \mathrm{Cl}^{-}$cotransport, furosemide reduced basolateral chloride entry in enterocytes and impaired active chloride secretion ${ }^{[11]}$. Isc changes translating a secretory response correspond to $\mathrm{Cl}^{-}$secretion. These 
changes reported in intestinal permeability were associated with local intestinal anaphylaxis and were suggestive of a mast cell mediator involvement. Previous studies demonstrated the potential involvement of histamine in inflammatory response by affecting ion secretion trough histamine $\mathrm{H} 1$ receptors ${ }^{[12,13]}$. In accordance with previous reports, increase in $\mathrm{G}$ produced by $\beta$-Lg or whey indicated that immunization alters the tight junction and increases the para-cellular permeability of the intestinal epithelium ${ }^{[14,15]}$.

Morphological changes in the epithelium due to the immunologic reaction were underscored by histological results demonstrating a villi atrophy and greater increase of mucosal inflammatory cells in jejunum. Similar results were observed in the jejunum of rat immunized with milk proteins ${ }^{[14]}$.

\section{CONCLUSION}

In conclusion, in the animal model obtained by the parenteral immunization of $\mathrm{Balb} / \mathrm{c}$ mice with $\beta$ - $\mathrm{Lg}$ or whey, IgG1 and IgE antibodies were highly induced, electrogenic chloride secretion was produced and the intestine morphology was profoundly affected. This murine model might be considered interesting and might be used to approach pathophysiological mechanisms of cow's milk allergy or to assess the allergenic potential of hydrolyzed formulae.

\section{REFERENCES}

1. Saarinen, K.M., K. Juntunen-Backman, A.L. Järvenpää, P. Kuitunen and E. Savilahti, 1999. Supplementary feeding in maternity hospitals and the risk of cow's milk allergy: A prospective study of 6209 infants. J. Allerg. Clin. Immunol., 104: 457-461. http://www.ncbi.nlm.nih.gov/pubmed/10452771

2. Untersmayr, E. and E. Jensen-Jarolim, 2006. Mechanism of type I food allergy. Pharmacol. Therapeutic, 112: 787-798. DOI: 10.1016/j.pharmthera.2006.06.004

3. MacDonald, T.T., 1995. Evidence for cellmediated hypersensitivity as an important pathogenic mechanism in food intolerance. Clin. Exp. Allerg., 25: 10-13. DOI: 10.1111/j.13652222.1995.tb01125.x

4. Bischoff, S. and S. Crowe, 2005. Gastrointestinal food allergy: New insights into pathophysiology and clinical perspectives. Gastroenterology, 128: 1089-1113. http://linkinghub.elsevier.com/retrieve/pii/S001650 8504014052

5. Strobel, S. and J.O.B. Hourihane, 2001. Gastrointestinal allergy: Clinical symptoms and immunological mechanism. Pediatr. Allerg. Immunol., 12: 43-46. DOI: 10.1034/j.1399-3038.2001.121410
6. Perdue, M.H. and D.G. Gall, 1986. Intestinal anaphylaxis in the rat: Jejunal response to in vitro antigen exposure. Am. J. Physiol., 250: G427-G431. http://ajpgi.physiology.org/cgi/content/abstract/250 /4/G427

7. Addou-Benounane, S., D. Tomé, O. Kheroua and D. Saidi, 2004. Parenteral immunization to $\beta$ lactoglobulin modifies the intestinal structure and mucosal electrical parameters in rabbit. Int. Immunopharmacol., $\quad 4$ : 1559-1563. http://www.cababstractsplus.org/abstracts/Abstract. aspx?AcNo=20043172408

8. Heyman, M., M. Adriantsoa and A.M. Crain-Denoyelle, 1990. Effect of oral or parenteral sensitization to cow's milk on mucosal permeability in guinea pig. Int. Arch. Allerg. Applied Immunol., 92: 242-246. http://www.ncbi.nlm.nih.gov/pubmed/2276841

9. Westphal, C.D. and R.B. Raybourne, 2004. Potential allergenicity of novel proteins in murine models. J. AOAC. Int., 87: 1433-1440. http://www.cababstractsplus.org/abstracts/Abstract. aspx?AcNo=20053000086

10. Strobel, S. and A.M. Mowat, 1998. Immune responses to dietary antigens: Oral tolerance. Immunol. Today, 19: 173-181. http://www.ncbi.nlm.nih.gov/pubmed/9577094

11. Poonyachoti, S. and D.R. Brown, 2001. $\delta$-opiod receptors inhibit neurogenic intestinal secretion evoked by mast cell degranulation and type I hypersensitivity. J. Neuro Immunol., 112: 89-96. http://www.ncbi.nlm.nih.gov/pubmed/11108937

12. Homaidan, F.R., J. Tripodi, L. Zhao and R. Burakoff, 1997. Regulation of ion transport by histamine in mouse cecum. Eur. J. Pharmacol., 3313: 199-204. http://www.ncbi.nlm.nih.gov/pubmed/9274980

13. Wang, Y.Z., H.C.Cooke and R. Fertel, 1990. Histamine augments colonic secretion in guinea pig distal colon. Am. J. Physiol., 258: 432-439. http://ajpgi.physiology.org/cgi/content/abstract/258 /3/G432

14. Mehedi, N., H. Kaddouri, D. Saidi and O. Kheroua, 2007. Effect of oral and parenteral sensitization to bovine $\beta$-lactoglobulin on intestinal structure in rats. Dirasat, Pure Sci., 34: 58-66. http://dar.ju.edu.jo/DirasatOnline/main.asp

15. Terpend, K., M.A. Blaton , C. Candalh, J.M. Wal, P. Pochart and M. Heyman, 1999. Intestinal barrier function and cow's milk sensitization in guinea pigs fed milk or fermented milk. J. Pediatr. Gastroenterol. Nutr., 28: 191-198. http://cat.inist.fr/?aModele $=$ afficheN\&cpsidt $=1657$ 207 